University of Montana

ScholarWorks at University of Montana

\title{
Climate Correlates of 20 Years of Trophic Changes in a High- Elevation Riparian System
}

Thomas E. Martin

University of Montana - Missoula, tom.martin@umontana.edu

Follow this and additional works at: https://scholarworks.umt.edu/wildbio_pubs

Part of the Life Sciences Commons

Let us know how access to this document benefits you.

\section{Recommended Citation}

Martin, Thomas E., "Climate Correlates of 20 Years of Trophic Changes in a High-Elevation Riparian System" (2007). Wildlife Biology Faculty Publications. 16.

https://scholarworks.umt.edu/wildbio_pubs/16

This Article is brought to you for free and open access by the Wildlife Biology at ScholarWorks at University of Montana. It has been accepted for inclusion in Wildlife Biology Faculty Publications by an authorized administrator of ScholarWorks at University of Montana. For more information, please contact scholarworks@mso.umt.edu. 


\title{
CLIMATE CORRELATES OF 20 YEARS OF TROPHIC CHANGES IN A HIGH-ELEVATION RIPARIAN SYSTEM
}

\author{
Thomas E. Martin ${ }^{1}$ \\ USGS Montana Cooperative Wildife Research Unit, University of Montana, Missoula, Montana 59812 USA
}

\begin{abstract}
The consequences of climate change for ecosystem structure and function remain largely unknown. Here, I examine the ability of climate variation to explain long-term changes in bird and plant populations, as well as trophic interactions in a high-elevation riparian system in central Arizona, USA, based on 20 years of study. Abundances of dominant deciduous trees have declined dramatically over the 20 years, correlated with a decline in overwinter snowfall. Snowfall can affect overwinter presence of elk, whose browsing can significantly impact deciduous tree abundance. Thus, climate may affect the plant community indirectly through effects on herbivores, but may also act directly by influencing water availability for plants. Seven species of birds were found to initiate earlier breeding associated with an increase in spring temperature across years. The advance in breeding time did not affect starvation of young or clutch size. Earlier breeding also did not increase the length of the breeding season for single-brooded species, but did for multi-brooded species. Yet, none of these phenology-related changes was associated with bird population trends. Climate had much larger consequences for these seven bird species by affecting trophic levels below (plants) and above (predators) the birds. In particular, the climate-related declines in deciduous vegetation led to decreased abundance of preferred bird habitat and increased nest predation rates. In addition, summer precipitation declined over time, and drier summers also were further associated with greater nest predation in all species. The net result was local extinction and severe population declines in some previously common bird species, whereas one species increased strongly in abundance, and two species did not show clear population changes. These data indicate that climate can alter ecosystem structure and function through complex pathways that include direct and indirect effects on abundances and interactions of multiple trophic components.
\end{abstract}

Key words: bird breeding phenology; bird populations; climate change; ecosystem structure; habitat selection; nest predation; plant populations; riparian systems; snowfall; trophic interactions; ungulate browsing.

\section{INTRODUCTION}

Changes in climate have been associated with shifts in phenology, distribution, and abundances of diverse organisms (Martin 2001, McCarthy et al. 2001, Root et al. 2003). Yet, the influence of climate on the structure and function of local ecosystems remains largely unstudied (McCarthy et al. 2001). We do not know, for example, whether changes in abundance of species in local ecosystems reflect simple redistribution in response to climate change, or more complex alteration of trophic and species interactions that influence population processes within the ecosystem. Do communities migrate intact and retain basic trophic structure and interactions, or do coexisting species respond in an individualistic manner and disrupt trophic interactions in response to climate (Root and Schneider 1995, Parmesan and Yohe 2003)? First inference can be provided by examining correlations of climate variation with long-term changes in abundanc-

Manuscript received 16 November 2005; revised 9 June 2006; accepted 11 July 2006; final version received 28 August 2006. Corresponding Editor: E. Siemann.

${ }^{1}$ E-mail: tom.martin@umontana.edu es, population processes, and trophic interactions for diverse species within an ecosystem. Here, I consider the possible influence of 20 years of climate variation for the structure and function of a high-elevation riparian ecosystem. I first examine three hypotheses for population changes in plants, and then examine four hypotheses for population changes in seven bird species based on possible direct and indirect effects of climate.

Winter precipitation hypothesis.-Physiological studies of water use show that deciduous trees in this habitat (i.e., quaking aspen, Populus tremuloides; canyon maple, Acer grandidentatum; New Mexican locust, Robinia neomexicana) depend almost solely on winter precipitation, whereas the dominant coniferous trees (white fir, Abies concolor; Douglas-fir, Pseudotsuga menziesii; ponderosa pine, Pinus ponderosa) are much less dependent on it (Phillips and Ehleringer 1995, Schwinning et al. 2002, Williams and Ehleringer 2000). Thus, if winter precipitation is limiting plant abundances, deciduous tree abundances should be positively correlated with winter precipitation, whereas conifer abundances should not, and deciduous and conifer abundances should vary independent of each other. 
Snow and ungulate browsing hypothesis.-Elk (Cervus elaphus), in particular, but also mule deer (Odocoileus hemionus), are abundant in this system and browse deciduous woody vegetation most heavily in winter (Cook 2002). Elk browse maple relatively heavily in winter, but not in other seasons (Mower and Smith 1989), and they browse aspen in all seasons, but least heavily in summer (reviewed in Cook 2002). This browsing pressure on deciduous plants can severely restrict recruitment and increase mortality, causing a decline in abundance (Bartos and Mueggler 1981, Kay 1993, Romme et al. 1995, Baker et al. 1997, Berger et al. 2001). Browsing pressure, in turn, is affected by snow because even with relatively minimal snow accumulation, energy costs for elk increase and diet quality declines (Cook 2002). As a result, elk move to lower elevations when snow depth increases (Sweeney and Steinhoff 1976, Leege and Hickey 1977). Indeed, elk move out of my study area to lower elevations in winters of greater snowfall (Brown 1994), thereby reducing browsing pressures in winters of high snowfall. Thus, abundances of deciduous, but not coniferous, woody vegetation should increase with snowfall, and deciduous and coniferous tree abundances should vary independently of each other. Snowfall is a component of winter precipitation; thus, the two hypotheses cannot be fully separated from each other. However, rainfall and snowfall, the two components of winter precipitation, vary somewhat independently, allowing an initial test of the two alternatives.

Succession hypothesis.-Deciduous trees decline in abundance in some systems because they are replaced by conifers due to fire suppression or natural succession (Romme et al. 1995, White et al. 1998, Hessl 2002). Thus, deciduous tree densities should vary inversely with conifer densities under this hypothesis.

I also explore hypotheses of population changes in seven bird species because species differ in ecological requirements and can differentially indicate environmental change induced by climate.

Phenological hypothesis.-Earlier breeding in warmer years has been documented for diverse bird species (Crick et al. 1997, Stevenson and Bryant 2000, Root et al. 2003). Earlier breeding may disrupt interactions with food and cause greater starvation and smaller young (Visser et al. 1998, Both and Visser 2001), which may cause declines in populations. Conversely, earlier breeding may be associated with larger clutch sizes (Winkler et al. 2002) or longer breeding seasons, thereby providing a positive effect on fecundity and population trends.

Habitat change hypothesis.-For birds, density and species composition of vegetation has the potential to influence habitat selection and nest predation risk, both of which can influence bird abundances (e.g., Martin 1998, 2001). In particular, annual abundances of the seven species should decrease and nest predation rates should increase with decreased densities of plants that represent their preferred nesting habitat (as detailed in Martin [1998]).

Nest predation hypothesis.-Nest predation is commonly the primary cause of reproductive mortality, and increases in nest predation are associated with decreased population size in the next year (Martin 1992, Johnson and Geupel 1996, Dececco et al. 2000, Sillett et al. 2000). Nest predation rates may increase with decreased vegetation density (see previous hypothesis), but also may be independently increased by effects of summer precipitation on increased predator abundances or decreased availability of alternative prey (McShea 2000).

Shifting distribution hypothesis.-Distributions of species may shift because local abundances of species may be directly related to physiological tolerances and weather that influence settling responses (see Root and Schneider 1995, Martin 2001). In particular, we might expect species that use mesic habitat conditions to increase in wet years and species that use more xeric habitat conditions to increase in dry years (Martin 2001).

I examined these hypotheses based on data from a 20year study that included detailed demographic data from 4118 nests of seven bird species, as well as careful study of plants based on stem counts in 9071 sampling plots.

\section{Study Area And Methods}

\section{Study area}

Study sites were 22 snowmelt drainages on the Mogollon Rim in central Arizona, USA, at an elevation of $\sim 2400 \mathrm{~m}$ (see Appendix A). Plots were relatively shallow valleys that included the entire width of the valley to the ridge tops on both sides (see Martin [2001] for a schematic drawing), 150-225 $\mathrm{m}$ wide, and have permanently marked stations at $25-\mathrm{m}$ intervals down the center of the drainage. Drainages were typically $\sim 25$ stations (or $625 \mathrm{~m}$ long), 8-14 ha each, most being $\sim 10$ ha. The drainages represented a mix of deciduous and coniferous plants, whereas the surrounding forest was characterized by open ponderosa pine (Martin 1998, 2001). Canopy trees were quaking aspen, Douglas-fir, white fir, ponderosa pine, and white pine. The understory included canyon maple (see Plate 1), New Mexican locust, saplings of overstory tree species, golden pea (Thermopsis pinetorum), and various grasses. Plant species composition and abundance varied predictably up the sides of the drainages as conditions changed from mesic at lower reaches to more xeric at higher reaches (Martin 1998). In particular, canyon maple and aspen were most abundant at lower reaches, whereas New Mexican locust was more abundant higher on the slopes (Martin 1998, 2001).

\section{Plant sampling}

Plant densities were measured following the national Breeding Biology Research and Monitoring Database (BBIRD) protocol (Martin et al. 1996). Beginning in 



Plate. 1. (Left) A typical canyon maple stand showing the browse line and lack of understory vegetation below browse height. Note the dead understory limbs from over-browsing and the open area in the forefront. Historically, stands such as this would have a thick understory. Many maple and quaking apsen ramets exist throughout this stand but are browsed down. (Right) The hermit thrush is one of the focal avian study species using ths habitat. Photo credits: T. E. Martin.

1987 (see Appendix B), to examine annual changes in plant densities, numbers of woody stems $>25 \mathrm{~cm}$ tall were counted for each plant species in sampling circles of $5 \mathrm{~m}$ radius at stratified random sites (Martin 1998). The gradient in plants up the sides of drainages (see Study area and methods: Study area) was stratified for sampling by placing five $5 \mathrm{~m}$ radius sampling circles equidistant up the sides of plots at every other station (i.e., every $50 \mathrm{~m}$ ) and alternating sides of the plot to capture any effects of differing aspect exposure on plant populations (see Martin [1998] for further details of sampling).

Aspen is a historical constituent of the canopy, but has become uncommon, with few young recruits, as seen in many other western systems (e.g., Bartos and Mueggler 1981, Kay 1993, Romme et al. 1995, White et al. 1998, Hessl 2002). Consequently, aspen is poorly sampled in the 5-m circles. Canopy aspen have been dying and falling at a steady rate throughout this study. I implemented sampling in 1995 to document trends. We permanently tagged all aspen (dead or alive) with dbh $>$ $12 \mathrm{~cm}$ encountered within $25 \mathrm{~m}$ of the center in each of 15 drainages (878 total aspens) and classified them as alive (all branches alive), dying (some branches dead), or dead (snag). Each year, field assistants resample all marked trees and reclassify each into these three categories, or down (fallen).

\section{Bird species and sampling}

Thirty-two species of birds occur regularly on the study plots. I focused on the seven most abundant species that nest on the ground or in shrubs, because I could obtain the largest and most reliable samples of nests and population processes for these species. The ground-nesters include Virginia's Warbler (Vermivora virginiae), Gray-headed Junco (Junco hyemalis caniceps), Red-faced Warbler (Cardellina rubrifrons), and Orangecrowned Warbler (Vermivora celata), which differ in nest site selection along the vegetation gradient (Martin 1998). The shrub-nesters include Green-tailed Towhee (Pipilo chlorurus), MacGillivray's Warbler (Oporornis tolmiei), and Hermit Thrush (Catharus guttatus; see Plate 1).

Individuals of all bird species were counted on the same nine plots from mid-May to mid-June each year from 1985 through 2005 (except 1990 due to a lapse in funding), using the plot-mapping technique (Christman 1984, Martin 2001) to index annual changes in abundance. I conducted all censuses in all years to control for possible observer differences. My censuses were supplemented with territory maps made by each nest-searcher, who visited the plots every other day for the entire field season (see Martin [2001] for details). Most plots were 25 stations in length $(625 \mathrm{~m})$, but three plots were shorter. Bird abundance was standardized to numbers of pairs per the standard $625 \mathrm{~m}$ length across all plots.

Drainages were searched for bird nests from May through July in 1987-2005. Nests were located by following adults and carefully monitored for clutch size, predation, starvation, and fledging rates using standardized long-term protocols (Martin and Geupel 1993, Martin 1998, 2001). Daily predation rates were estimated following Mayfield (1975) and Hensler and Nichols (1981). The date when first eggs were laid was recorded for all nests found during nest construction and egglaying, or was back-calculated when hatching was 

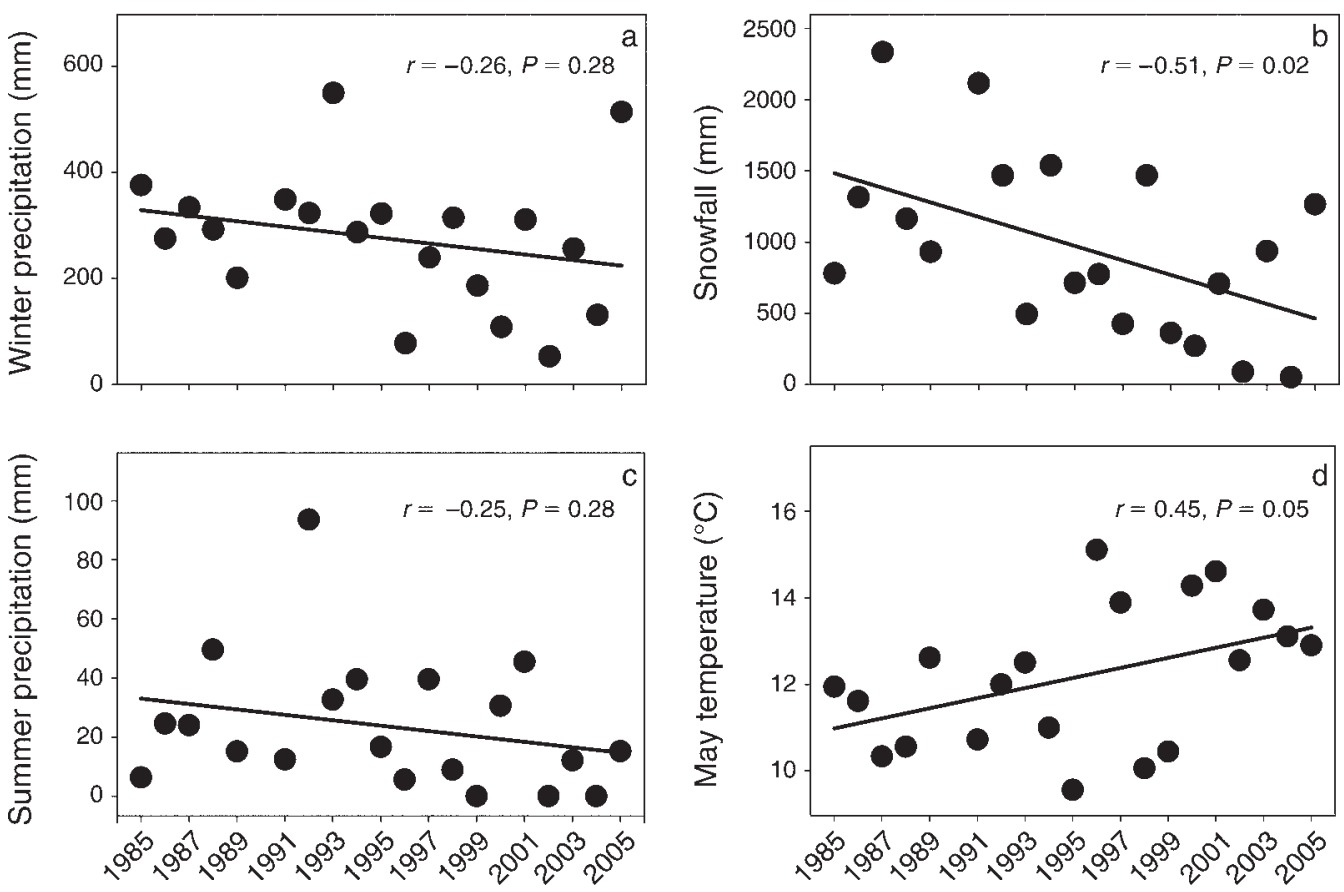

FIG. 1. Climate variation among years. (a) Average annual variation in winter precipitation (total precipitation from October through March) was not correlated with year, although if 2005 is excluded, then winter precipitation decreased across the remaining years $(r=-0.50, P=0.03$ ). (b) Annual snowfall (total snowfall from October through March) decreased over time. (c) Annual summer (May and June) precipitation did not decline significantly over time, even if the outlier year was excluded. (d) Average May (period of territory settlement and nest initiation) temperature increased across years.

observed, to examine breeding date relative to weather. Duration of the breeding season was calculated as the span of days between earliest and latest initiation dates for the middle $90 \%$ of nests of each species in each year; the earliest and latest $5 \%$ of initiations were excluded due to small samples at the tails.

\section{Climate variation}

Variation in climate was measured using National Oceanic and Atmospheric Administration (NOAA) data from the Blue Ridge Ranger Station, which is located $15-30 \mathrm{~km}$ from individual study plots at the same elevation (see Appendix C). Winter snow and winter precipitation were estimated as total snowfall and total precipitation from October through March. Breeding season climate was measured as total precipitation and average temperature during May and June, because these are the primary months of territory establishment and nest initiation.

\section{Statistical analyses}

Global models of analysis of covariance (ANCOVA) were used for each dependent variable, where species was the main factor and hypothesized causal factors were covariates. Interactions were also tested, but were removed and not reported when not significant. This approach served two purposes. First, it included experiment-wise error to minimize multiple testing issues. Second, it incorporated the added power of examining multiple species simultaneously. I included species as a factor in order to nest covariate relationships within species and not to test a main effect of differences among species. Consequently, significant interactions did not compromise the test as long as species varied in the same direction. In cases where significant interactions reflected relationships in opposite directions, then analyses were conducted separately. In such cases, backward-elimination multiple regression was used because all variables in the analysis were hypothesized a priori to be influential. Trend analyses of climate measures and bird abundances were based on simple linear regression because I was interested in simply knowing if unidirectional trends existed over the study period, rather than finding the best-fit model.

\section{Results}

\section{Climate variation}

Winter precipitation did not decrease with time, although exclusion of the high-precipitation winter of 2004-2005 suggested a decline (Fig. 1a). Total snowfall decreased significantly over the 20 years of this study (Fig. 1b). Winter precipitation and snowfall were weakly correlated across years (for all years, $r=0.45, P=0.049$; with exclusion of $2005, r=0.44, P=0.058$ ), but only about $20 \%$ of the variance was explained. Thus, these two measures still exhibit substantial independent 

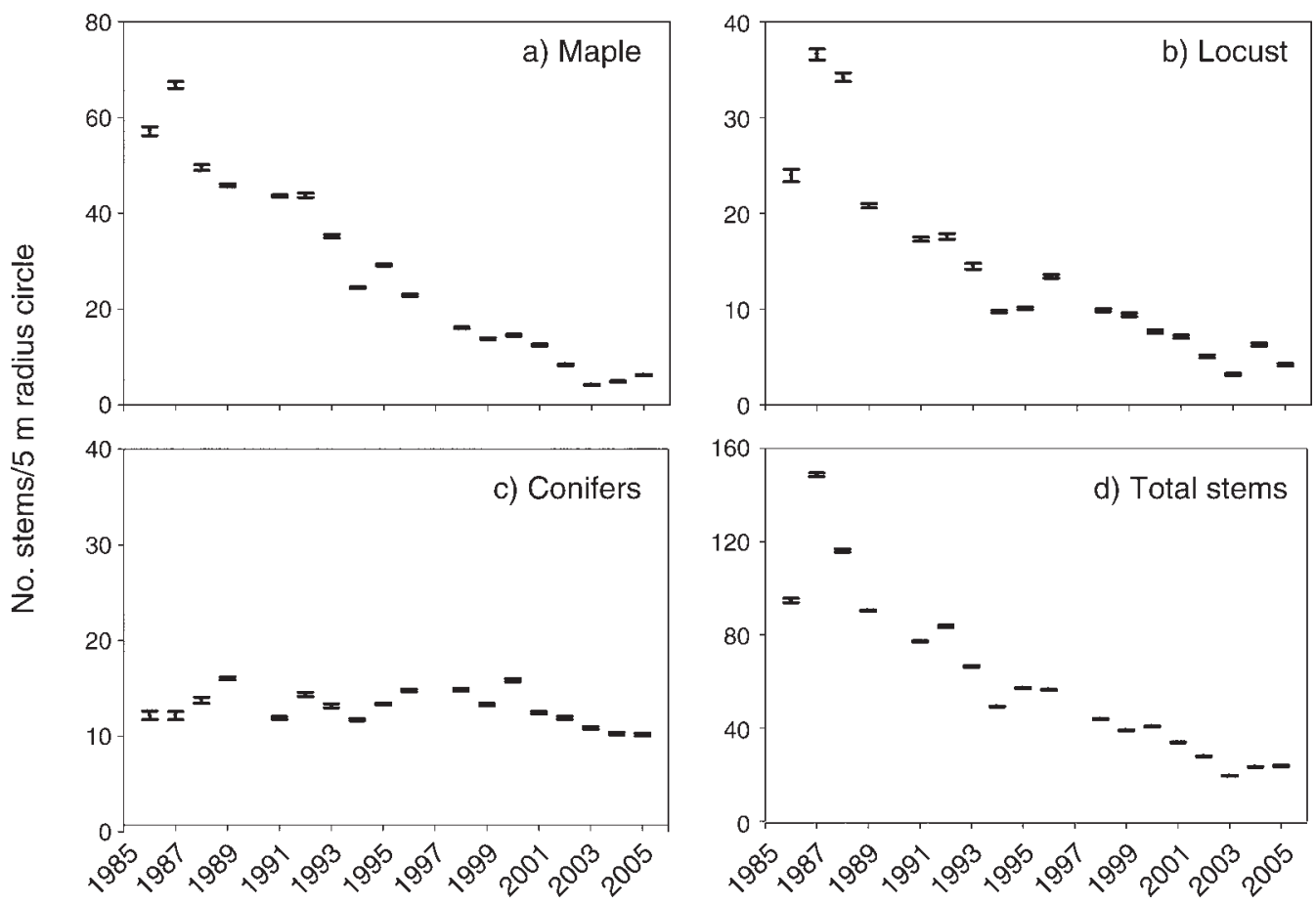

FIG. 2. Density (mean $\pm \mathrm{SE}$ ) of dominant woody plant species across years (number of stems within a $5 \mathrm{~m}$ radius circle, $n=$ 400-600 sample plots/year except the first two years). (a) Canyon maple (Acer grandidentatum) and (b) New Mexican locust (Robinia neomexicana) declined dramatically across years. (c) Numbers of conifers (primarily white fir and Douglas-fir) remained relatively steady. (d) Total woody stems, comprising mostly deciduous species, decreased strongly over the years of sampling, reflecting the decline in deciduous vegetation.

variation; rain or snow can occur in all months of winter.

Summer precipitation (May and June) did not decline across the 20 years of study (Fig. 1c), although the study period included the driest and wettest summers on record. Summer precipitation did not covary with winter precipitation $(r=0.26, P=0.27)$ or snowfall $(r=0.26, P$ $=0.27$ ). Temperature during May (the period when territories are established and nests are initiated) increased over time (Fig. 1d). Variation in May temperature was not correlated with summer precipitation $(r=0.04, P=0.86)$ or winter precipitation $(r=$ $-0.31, P=0.17)$. However, years with more snowfall were associated with cooler May temperatures $(r=$ $-0.49, P=0.027)$, although again only $24 \%$ of the variation was explained. Thus, the four climate variables showed substantial and largely independent variation over the 20 years of study, with a clear decline in snowfall and possibly winter precipitation, and an increase in May temperatures (Fig. 1).

\section{Plant variation}

Densities of the two dominant deciduous plant species (i.e., maple, locust) and total number of woody stems declined dramatically over the 20 years of study (Fig. 2; see Appendix B). In contrast, densities of coniferous trees did not vary directionally over time (Fig. 2). Aspen is relatively uncommon in this system now, and direct monitoring of 878 aspen demonstrated strong declines in live trees (Fig. 3). With no recruitment to replace dead or dying trees, the projection of current rates of loss suggests that live aspen will be completely absent from the canopy by about the year 2010 (Fig. 3). Thus, all



FIG. 3. Annual change in percentage of quaking aspen (Populus tremuloides) that remain fully alive (1995-2005). An original sample of 878 trees was permanently marked in 1995, and only $51 \%$ were fully alive (all branches alive). This percentage declined as trees fell, died, or changed to partly dead. No new trees $(>12 \mathrm{~cm} \mathrm{dbh})$ were recruited during this period. At current observed rates of loss, all live canopy aspen are predicted to be lost by about 2010 . 


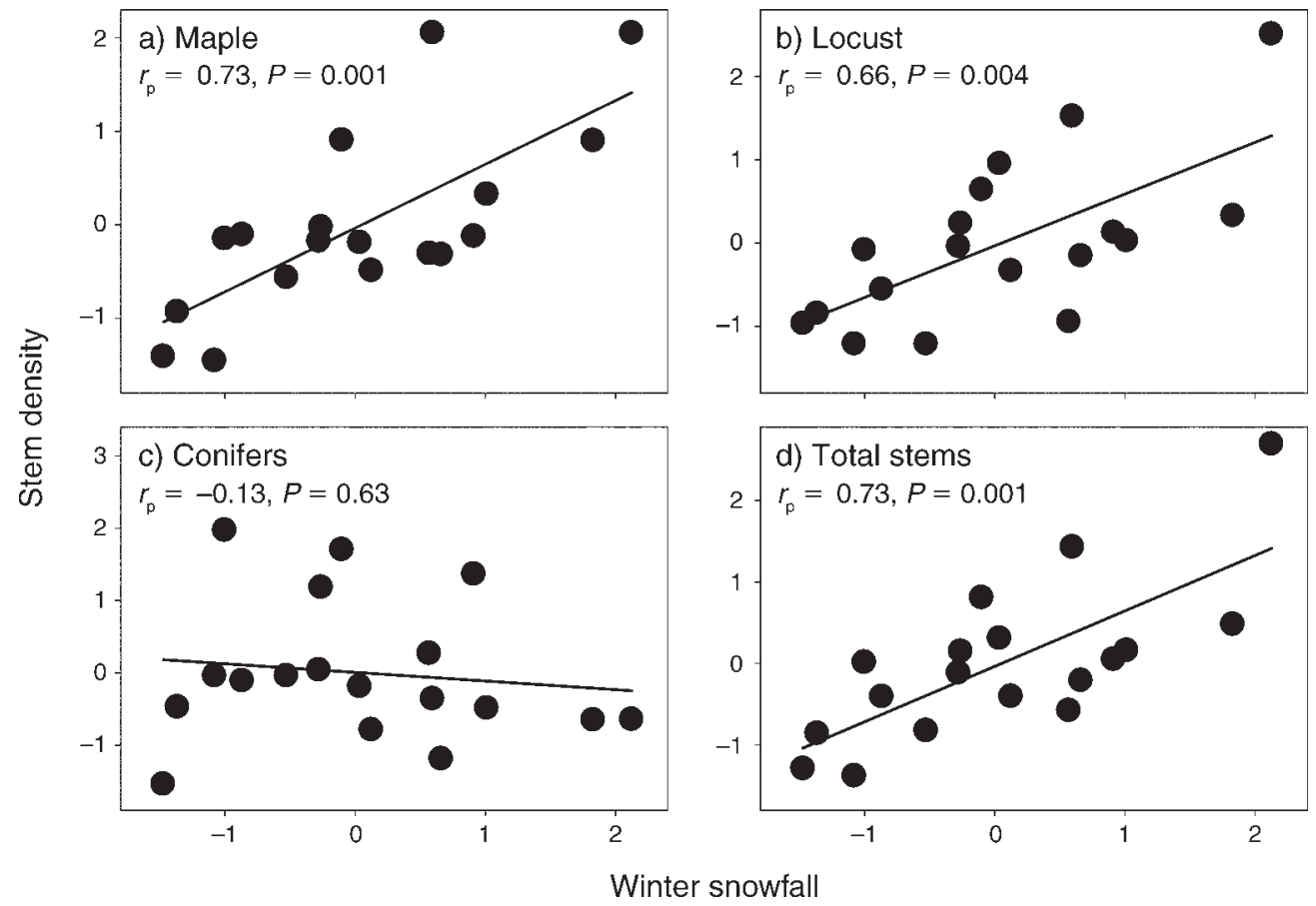

FIG. 4. Annual densities (numbers of stems within a $5 \mathrm{~m}$ radius sampling circle) of dominant woody plant species relative to prior winter (October through March) snowfall corrected for lag effects of snowfall two years prior. The figure presents plots of standardized data (in standard-deviation units, with mean $=0$ ); partial correlations $\left(r_{\mathrm{p}}\right)$ are also shown. (a) Maple and (b) locust decreased across years with decreased snowfall, whereas (c) conifers did not vary with snowfall. (d) Total woody plants, which consist mostly of deciduous stems, also declined across years with decreased snowfall.

major deciduous trees species declined, while conifers did not change.

The possible influence of climate on plant trends was examined separately for conifers and deciduous/total woody stems because of their different trends (Fig. 2). Possible lag effects of winter weather were examined by including snowfall and winter precipitation in the winters preceding, two years prior, and three years prior in one global model. Snowfall in the three winters was not correlated among years $(r<0.14, P>0.55$ in all cases), nor was winter precipitation in the three years $(r$ $<0.07, P>0.76$ in all cases). Declines in maple, locust, and total woody stems were strongly correlated with the decline in snowfall in the winters preceding, two years prior, and three years prior (Fig. 4; ANCOVA: for snowfall in the preceding year, $F_{1,35}=54.2, P<0.0001$; for snowfall two years prior, $F_{1,35}=44.8, P<0.0001$; for snowfall three years prior, $F_{1,35}=4.3, P=0.045$ ), but were not related to winter precipitation in any year (for winter precipitation in the preceding year, $F_{1,35}=2.5, P$ $=0.13$; for two years prior, $F_{1,35}=0.7, P=0.42$; for three years prior, $\left.F_{1.35}=0.1, P=0.81\right)$. The only significant interactions were with snowfall in the winters preceding and two years prior (for plant species $\times$ preceding year snowfall, $F_{2,35}=7.9, P=0.001$; for plant species $\times$ two years prior snowfall, $F_{2,35}=7.3, P=0.002$ ). Conifer abundances were not related to any of the winter snow or winter precipitation measures $\left(F_{1,9}<1.1, P>0.32\right.$ in all cases).

The decline in the deciduous species was not related to an increase in conifers. Conifers did not increase in the system (Fig. 2), and changes in densities of the deciduous species were not correlated with annual densities of coniferous trees $(r<0.28, P>0.26$ in all cases). Indeed, the habitat is relatively open canopy and now contains many large openings in which woody shrubs once existed, but are now without woody vegetation or canopy crown (personal observation).

In short, the dominant components of the vegetation of these drainages are deciduous trees, and all have declined dramatically over the course of the 20 years of study (Figs. 2 and 3), correlated with a decrease in winter snowfall (Fig. 4).

\section{Bird variation}

The seven bird species illustrated strong annual variation and long-term trends in abundances (Fig. 5). One previously common bird species (MacGillivray's Warbler) became locally extinct in all 20 study sites and all surrounding riparian drainages (personal observation) over the course of this study. A second species (Greentailed Towhee) has been nearly extirpated, while Orange-crowned Warblers declined steeply in abundance over the 20 years (Fig. 5). The Red-faced Warbler 

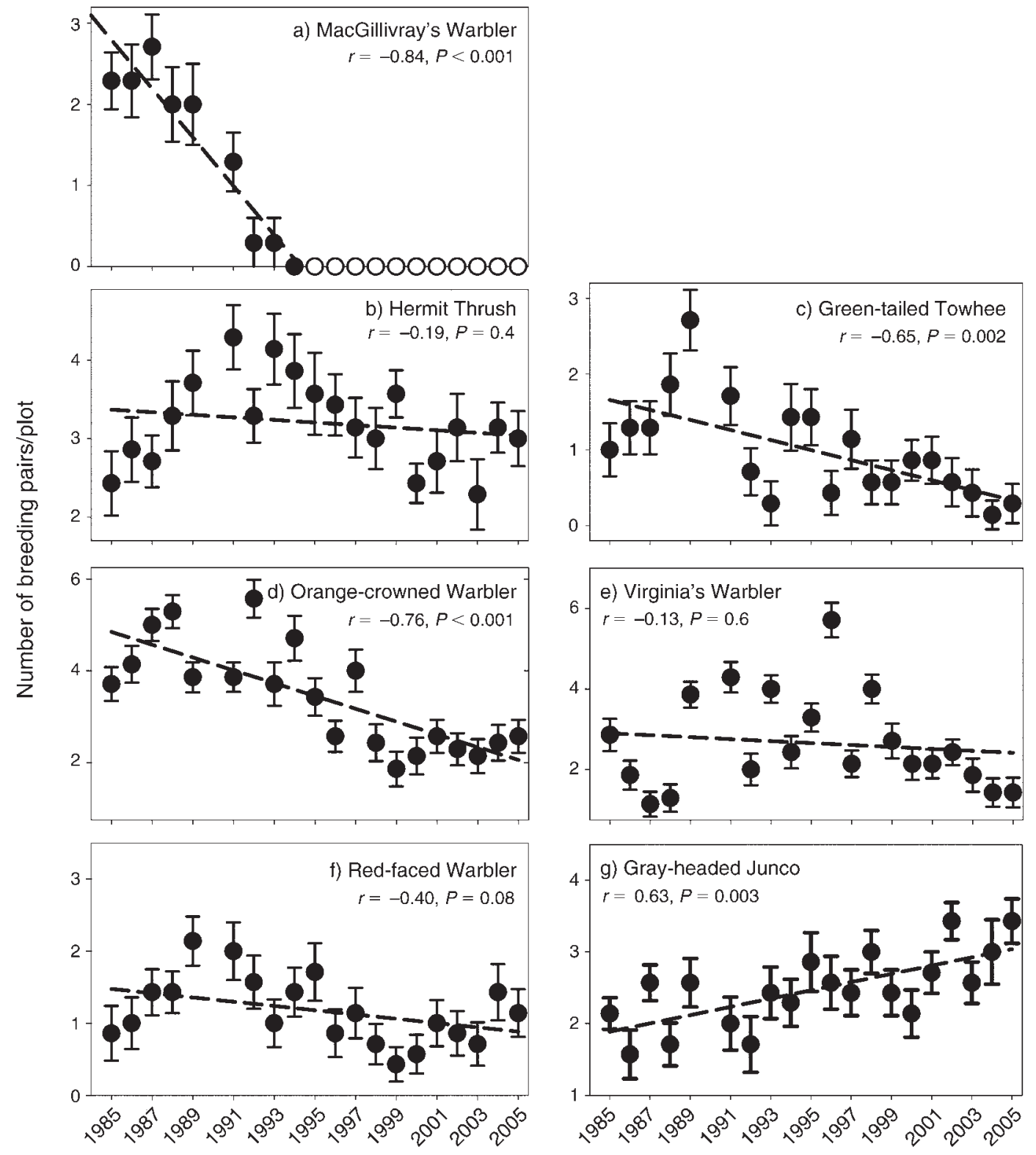

FIG. 5. Changes in densities (number of pairs per $625 \mathrm{~m}$ long plot, mean $\pm \mathrm{SE}$ ) of seven bird species across years. (a) MacGillivray's Warbler, (b) Hermit Thrush, and (c) Green-tailed Towhees are shrub-nesting species, whereas (d) Orange-crowned Warbler, (e) Virginia's Warbler, (f) Red-faced Warbler, and (g) Gray-headed Junco are ground-nesting species. Four of the seven species declined strongly in abundance over the 20 years of study. MacGillivray's Warbler exhibited a particularly extreme change: it was common in the early years and has been locally extinct for more than the past decade. A second species (Green-tailed Towhee) has been nearly extirpated. Only one species (Gray-headed Junco) increased in abundance. Numbers of pairs of breeding birds were counted on the same nine plots each year, except 1990 when fieldwork was missed.

showed a mild decline (Fig. 5). Only one bird species (Gray-headed Junco) increased in abundance, while the remaining two species did not exhibit clear unidirectional trends (Fig. 5).

Of the five bird species that were sufficiently abundant to determine nest initiation dates, all laid eggs earlier in years with warmer average May temperature (Fig. 6). Given the increase in May temperatures across years (Fig. 1), egg-laying has become earlier across years
(ANCOVA: for year, $F_{1,82}=9.4, P=0.003$; for species, $F_{4,82}=48.8, \quad P<0.001$; the interaction was not significant). Starvation is almost never observed in this system and the incidence of starvation did not increase in years of warmer May temperatures or with earlier nest initiation (ANCOVA: for species, $F_{4,67}=0.8, P=$ 0.53 ; for May temperature, $F_{1,67}=1.1, P=0.30$; for nesting initiation date, $F_{1,67}=0.8, P=0.39$; the interactions were not significant). Annual average clutch 



Average May temperature $\left({ }^{\circ} \mathrm{C}\right)$

FIG. 6. Average date that first eggs were laid in each year relative to average temperature in May (the period of initiation of $>98 \%$ of first nests) for five common species (the other two species could not be analyzed because of insufficient sample sizes in later years). Hermit Thrush and Gray-headed Junco are double-brooded, and the three warblers are single-brooded. Average date of first eggs was negatively related to average temperature during May across all species, and species did not differ in the rate of change in laying dates with temperature (for May temperature, $F_{1,82}=105.7, P<0.001$; for species, $F_{4.82}=101.9, P<0.001$; temperature $\times$ species was nonsignificant).

size of first nesting attempts also did not vary with May temperature or nesting initiation date (ANCOVA: for species, $F_{4,67}=1.5, P=0.20$; for May temperature, $F_{1,67}$ $=2.2, P=0.15$; for nesting initiation date, $F_{1,67}=0.8, P$ $=0.39$; interactions were not significant). Duration of the breeding season increased in years when breeding was initiated earlier for the two multi-brooded species (Gray-headed Junco and Hermit Thrush), but not for the three single-brooded warblers (Fig. 7). Finally, nest predation rates increased in drier summers (Fig. 8) and with decreased abundances of preferred plants (Fig. 9), but not with abundance of the bird species or the group of species in the relevant shrub- or ground-nesting guild (ANCOVA: for bird species, $F_{5,81}=7.9, P<0.0001$; for summer precipitation, $F_{1,81}=12.7, P<0.001$; for preferred plant species abundance, $F_{1,81}=5.8, P=0.019$; for bird species abundance, $F_{1,81}=0.3, P=0.57$; for guild abundance, $F_{1,81}=1.3, P=0.25$; for bird species $\times$ preferred plant species abundance, $F_{5,81}=3.0, P=$ $0.015)$.

Changes in abundances of bird species were explained by variation in deciduous vegetation, nest predation, and summer precipitation. Changes in abundances of all seven bird species were strongly correlated with changes in abundance of preferred habitat (Table 1). Precipitation at the time of settling (summer precipitation) explained additional residual variation in abundances of four of the six species that were present in all years (Table 1). Nest predation in the previous year explained additional variation in abundance of only one species, although it showed weak tendencies for smaller populations following years of higher nest predation in five of 

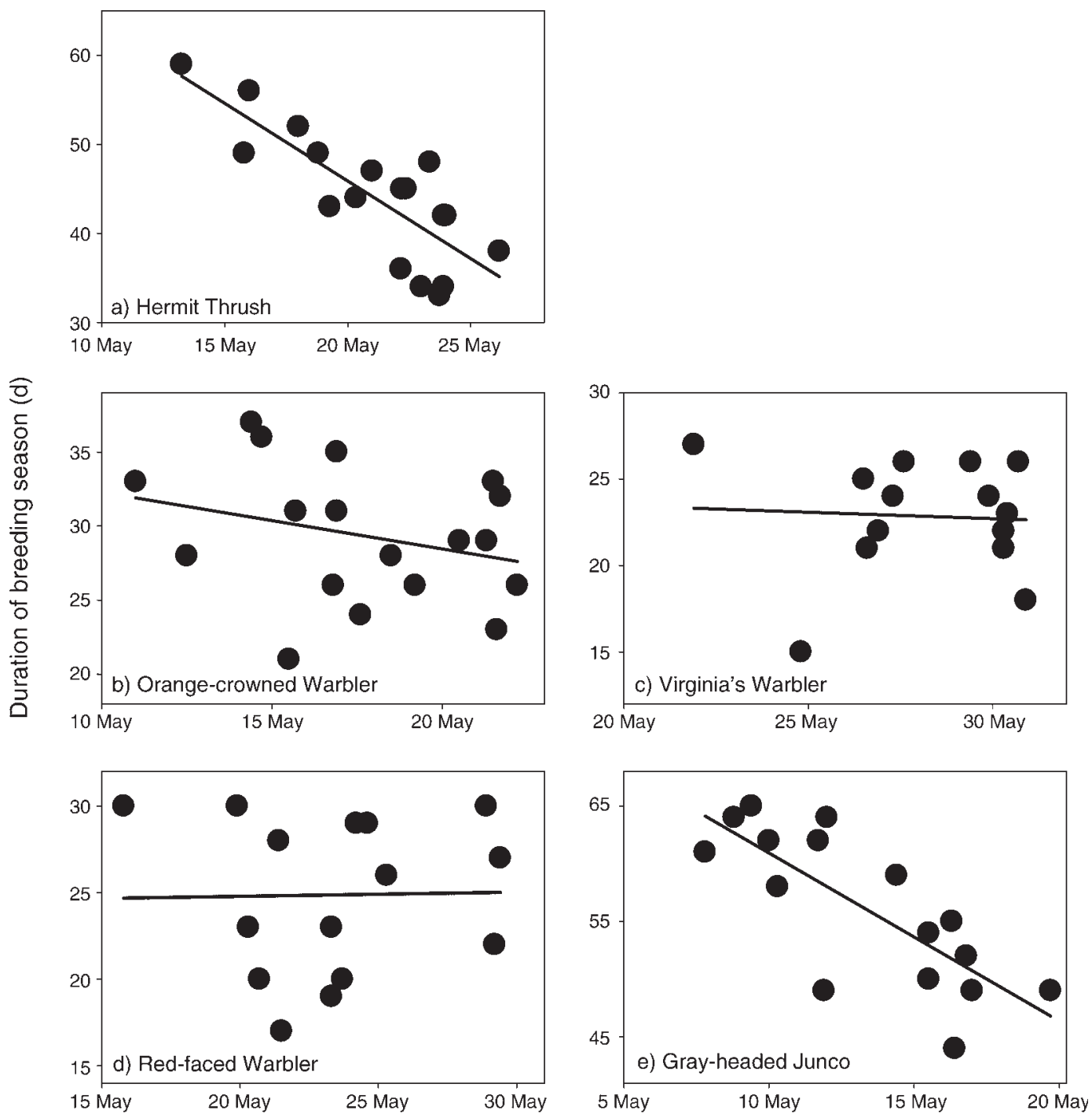

Average initiation date of first eggs

FIG. 7. Duration of the breeding period (the span of days between first and last nests initiated for the middle $90 \%$ of nest initiations, where the earliest and latest $5 \%$ were excluded) relative to the average date when first eggs were laid in each year. Singlevs. double-brooded species had a significant interaction for duration and nest initiation date (for initiation date $\times$ brood type, $F_{1,75}$ $=25.7, P<0.001$; for species within brood type, $F_{3,75}=1.8, P=0.16$ ), so the two brood types were analyzed separately. The breeding period was longer in years when nests were initiated earlier for double-brooded species (for initiation date, $F_{1,30}=51.0, P$ $<0.001$; for species, $F_{1,30}=0.4, P=0.5$; for species $\times$ initiation date, $F_{1,30}=0.4, P=0.5$ ), but not for single-brooded species (for initiation date, $F_{1,42}=0.2, P=0.6$; for species, $F_{2,42}=0.6, P=0.5$; for species $\times$ initiation date, $F_{1,42}=0.6, P=0.6$ ).

the six species (Table 1). The ability of nest predation in the previous year to explain additional variation in bird abundances was compromised because it is highly collinear with abundance of preferred habitat in the current year (ANCOVA: for preferred plant species abundance, $F_{1,74}=7.9, P=0.006$; for bird species, $F_{5,74}$ $=6.8, P<0.0001$; for bird species $\times$ preferred plant species abundance, $\left.F_{5,74}=2.3, P=0.057\right)$. Thus, preferred plant species abundance reflects both habitat availability and nest predation risk in the prior, and current (Fig. 9), year. Bird abundance in the current year is strongly negatively related to nest predation in the prior year when it is analyzed separately (ANCOVA: for nest predation in the prior year, the pooled slope $B=$ $-48.6 \pm 17.0$ (mean $\pm \mathrm{SE}$ ), $F_{1.91}=8.2, P=0.005$; for bird species, $F_{6,91}=18.9, P<0.0001$; the interaction was not significant).

\section{Discussion}

Both birds and plants showed strong changes in abundances across the 20 years of study (Figs. 2, 3, and $5)$, thereby reflecting a change in ecosystem structure. Not all plant and bird species changed in the same direction, indicating independence of components of the 

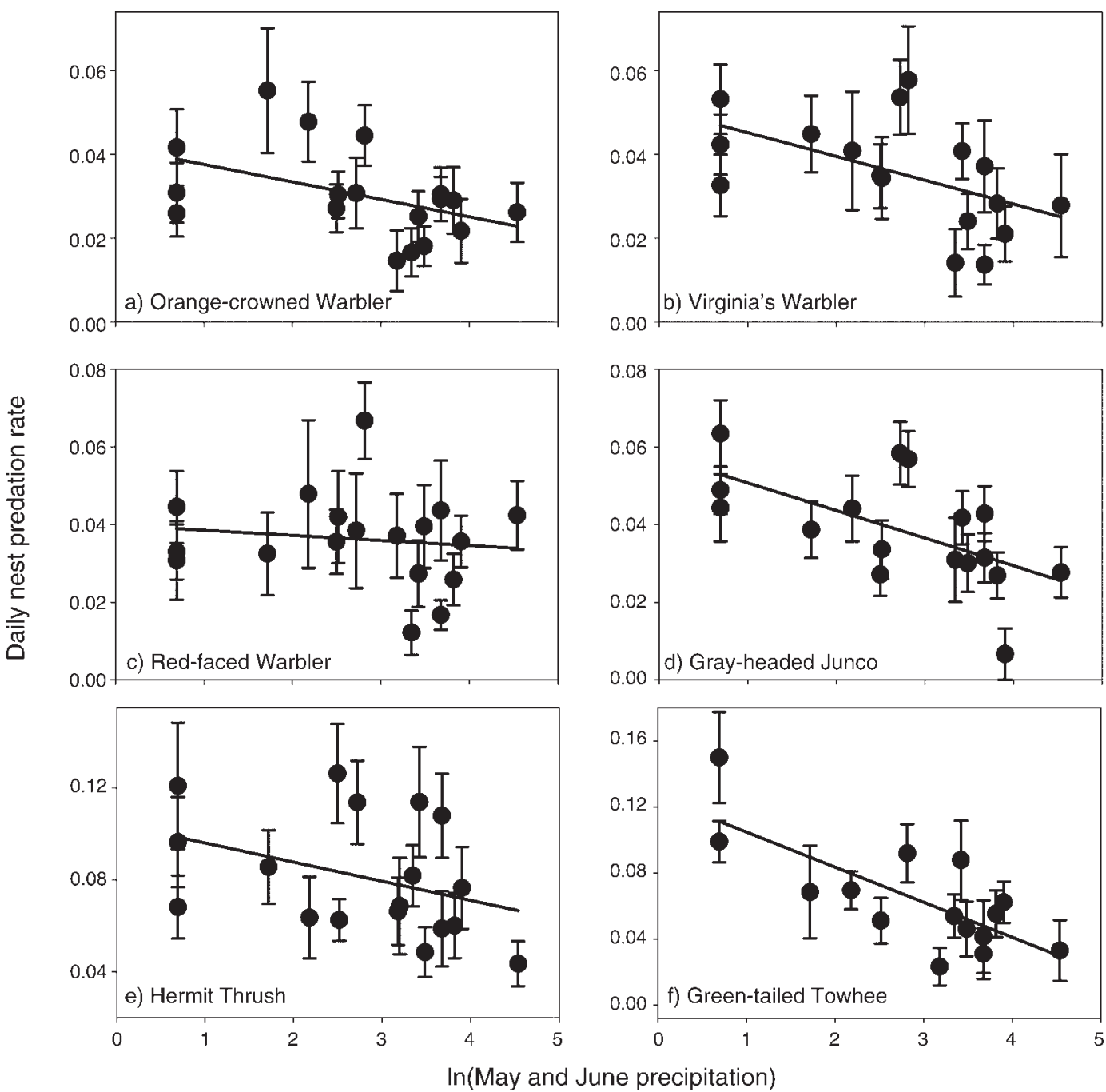

FIG. 8. Average daily nest predation rate (the probability of a nest being depredated per day) in each year relative to logtransformed summer (May and June) precipitation for six bird species. (MacGillivray's Warbler could not be analyzed because of insufficient sample sizes.)

ecosystem. At the same time, however, some species did change in the same direction, such as the decline in all deciduous tree species and a correlated decline in bird species that depended on these plants as habitat, suggesting that some components of the ecosystem are interdependent. In other words, ecosystem changes consist of both individualistic and interdependent responses among species and components. Most importantly, the changes at both levels are correlated with climate variability in ways that suggest both direct and indirect roles of climate.

The decline in deciduous woody plants could not be attributed to an increase in coniferous plants (Fig. 2), demonstrating that the loss of the deciduous elements was not simply a result of succession or fire suppression. Indeed, many areas previously occupied by deciduous woody plants are now open with no canopy cover (personal observation). Moreover, a direct role of climate through water limitation was not supported, given the lack of a correlation between plant abundance and winter precipitation. However, this direct effect cannot be totally ruled out yet because the likely effects of browsing may overwhelm water limitations, and the ability of snow to provide winter water as well as influence elk browsing may indicate that an interaction of the two could exist. Further studies to separate these effects are needed.

The correlation of the decline in deciduous plants with snowfall (Fig. 4) suggested a strong role of elk browsing. Elk populations exist at much higher population densities in forests in Arizona than they existed historically (O'Gara and Dundas 2002), but the population in the study area has not increased during the study period and has even declined slightly over the past 10 years (Arizona Game and Fish Report, unpublished manuscript). Thus, the decline in plants over the study period is not from increasing herd size. Instead, elk 

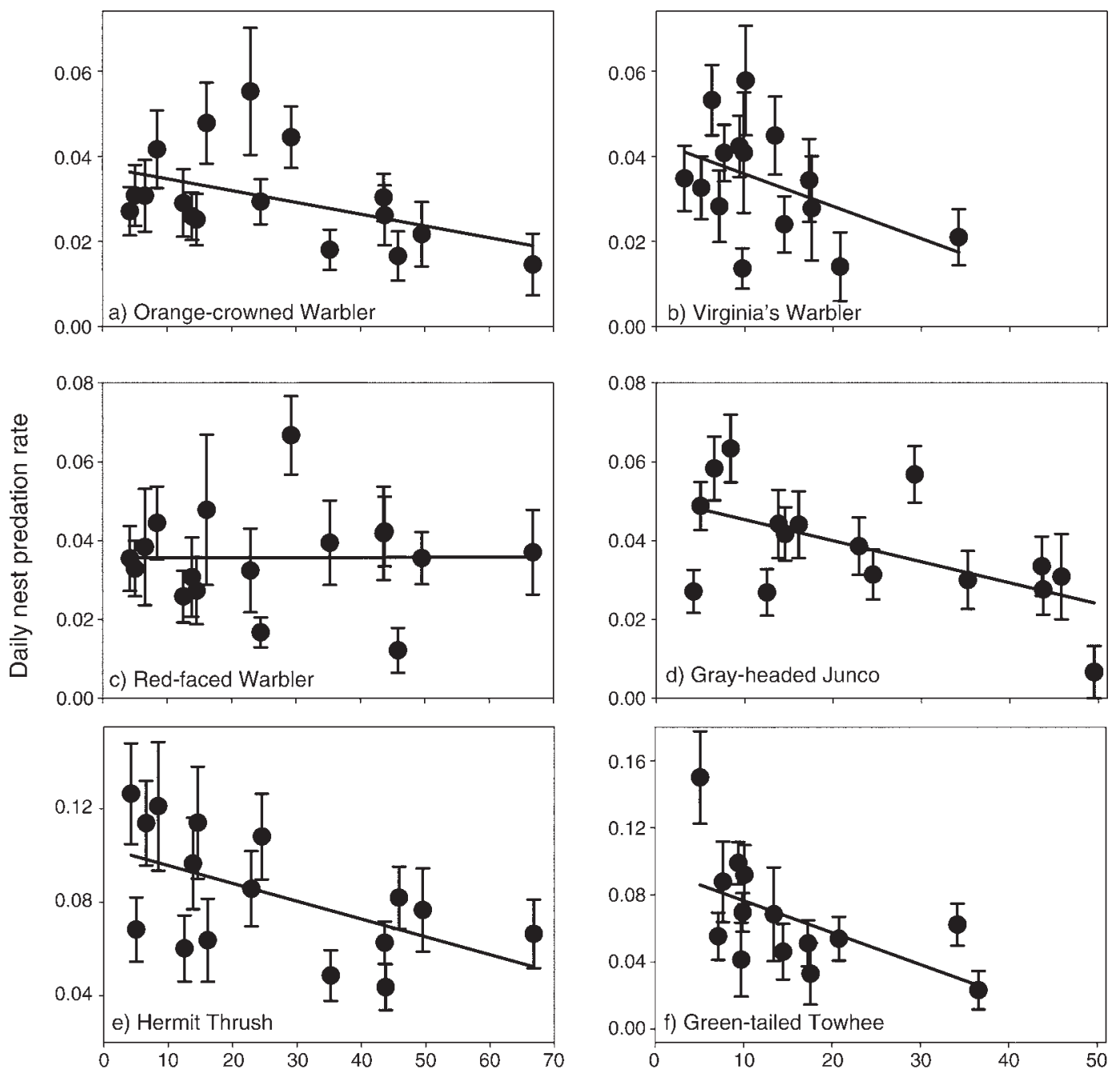

\section{Abundance of preferred habitat}

FIG. 9. Average daily nest predation rate (the probability of a nest being depredated per day) in each year relative to the abundance of preferred habitat for six bird species. (MacGillivray's Warbler could not be analyzed because of insufficient sample sizes.) Preferred habitat was the number of woody stems of vegetation preferred for nesting, as quantified in Martin (1998).

TABLE 1. Partial correlation coefficients of annual abundances of bird species relative to annual variation in preferred habitat, nest predation rates in the previous year, and summer (May and June) precipitation.

\begin{tabular}{lccc}
\hline \hline \multicolumn{1}{c}{ Species } & $\begin{array}{c}\text { Preferred } \\
\text { habitat }\end{array}$ & $\begin{array}{c}\text { Previous-year } \\
\text { nest predation }\end{array}$ & $\begin{array}{c}\text { Summer } \\
\text { precipitation }\end{array}$ \\
\hline Orange-crowned Warbler & $0.743^{* *}$ & -0.211 & $0.575^{*}$ \\
Virginia's Warbler & $0.805^{* *}$ & 0.112 & $-0.729^{* *}$ \\
Red-faced Warbler & $0.688^{* *}$ & -0.477 & 0.158 \\
Gray-headed Junco & $0.590^{*}$ & $-0.542^{*}$ & $-0.612^{*}$ \\
Hermit Thrush & $0.729^{* *}$ & -0.380 & $0.539^{*}$ \\
MacGillivray's Warbler & $0.863^{* *}$ & $\mathrm{NA}$ & $\mathrm{NA}$ \\
Green-tailed Towhee & $0.628^{* *}$ & -0.109 & -0.187 \\
\hline
\end{tabular}

Notes: Preferred habitat was defined as numbers of woody stems of the preferred vegetation determined in Martin (1998). Partial correlations are from backward-elimination multiple regression. NA indicates that data are not available due to insufficient sample sizes.

$$
{ }^{*} P<0.05 ; * * P<0.01 \text {. }
$$


move out of the study area to lower elevations in winters with greater snow accumulation (Brown 1994), but the long-term decline in snow accumulation (Fig. 1) has allowed elk to remain and to have an increased browsing impact on the deciduous woody vegetation. The browse line in this habitat is visually obvious: very little deciduous vegetation now exists below elk forage height. Such effects did not exist in the early years of the study (personal observation), when snow accumulation was much greater. Similarly, Post et al. (1999) reported that increased snow on Isle Royale enhanced understory plant growth because more snow increased rates of wolf predation on moose, which then reduced browsing pressures and yielded increased understory conifer growth. In both cases, climate exerted a significant indirect effect on the plant community through effects on abundance of a primary ungulate consumer.

Climate also appears to affect birds both directly and indirectly. Birds in Arizona join the growing evidence (see Root et al. 2003) that organisms are breeding earlier as spring gets progressively warmer (Fig. 6). The earlier breeding in this system did not appear to yield mismatched timing with respect to food resources, given that starvation rates and clutch size did not show any consistent correlated changes. Double-brooded species advanced laying date just as strongly as single-brooded species (Fig. 6), in contrast to populations of two Parus species (Visser et al. 2003). However, earlier breeding in the two double-brooded species (Hermit Thrush and Gray-headed Junco) allowed longer breeding seasons, which could exert positive effects on populations. Yet, such effects clearly did not explain population trends of Hermit Thrushes, which did not increase in later years when it was warmer (Fig. 5). Thus, a trend for warmer springs (Fig. 1) was associated with earlier breeding by all species (Fig. 6), but this phenological response did not explain population trends.

Climate appeared to affect birds most strongly through indirect effects on higher (predation) and lower (plants) trophic levels. Nest predation increased in drier summers (Fig. 8) and with decreased density of preferred habitat (Fig. 9), which was associated with decreased snowfall (Fig. 4). Nest predation is the overwhelming cause of reproductive failure (Martin 1992) and, not surprisingly, increased nest predation rates are associated with decreased population size in the next year (Martin 1992, Johnson and Geupel 1996, Dececco et al. 2000, Sillett et al. 2000). Results for the seven species here show smaller population sizes following higher nest predation rates in the prior year (see Results). Such results illustrate the subtle and complex ways in which climate can indirectly influence ecosystem function.

Birds are known to settle at higher densities where preferred nesting habitat is more abundant (Cody 1985, Petit and Petit 1996). The climate-associated change in vegetation (Fig. 4), which reflects preferred habitat of the birds in this system (Martin 1998), was strongly correlated with change in the bird populations (Table
1). The importance of change in preferred habitat is emphasized by the local extinction of the MacGillivray's Warbler, which averaged more than two pairs per plot in the early years of the study (Fig. 5). MacGillivray's Warblers depended on canyon maple for nesting (Martin 1998), and the loss of this bird species was very closely tied to the decline in maple over time (Table 1). This result reflects the importance of settling decisions; MacGillivray's Warblers move through the study plots every spring, but never settle (personal observation). This species might settle within this ecosystem once again if appropriate habitat were restored (i.e., dense maple patches). Of course, population sizes are also influenced by survival outside of the breeding season, which can be affected by climate (Sillett et al. 2000); thus population changes can also reflect extrinsic effects that are unmeasured in the breeding habitat. Nonetheless, birds here had the majority ( $53 \%$ to $82 \%$, with exception of Green-tailed Towhees at $42 \%$ ) of their annual variation in abundances explained by preferred nesting habitat abundance, nest predation, and summer precipitation (Table 1). The latter factor further emphasizes the potential role of climate on settling decisions; changes in abundance relative to climate at the time of settling (Table 1) suggest that birds are shifting their distributions (e.g., elevationally or latitudinally) in direct response to climate (Martin 2001). Thus, climate can influence densities of mobile organisms within an ecosystem through effects on intrinsic population processes (e.g., nest predation) and habitat selection decisions.

Alteration of trophic interactions seems to exist for other trophic levels within the ecosystem. For example, the decline in woody plants appears to reflect effects of climate on trophic levels above (ungulate herbivores) and may include a direct effect of changing water availability from below as well. The existence and consequences of altered trophic interactions for populations of the nest predators of birds are unknown; the primary nest predators in this system are small mammals (Martin 1998, 2001) and small-mammal populations have not been monitored. Thus, the increase in nest predation in drier summers could reflect a decrease in alternative prey (McShea 2000) or an increase in density of key mammalian predators in response to climate or the habitat changes. Ultimately, all of these possibilities and relationships emphasize the complex interlinkages among trophic levels of ecosystems and, as a result, the complex influences of climate that often may be subtle, given their sometimes indirect nature.

The decline in snowfall observed in my study area has been observed over the last half century throughout the mountains of western North America, and appears to reflect warming rather than declining winter precipitation (Hamlet et al. 2005, Mote et al. 2005). Climate models predict continued and substantial declines in snow levels in the Rocky Mountains through the next century, especially at the elevations of my study area (Fyfe and Flato 1999). Thus, the changes observed here 
could be widespread throughout western North America and could get worse. Certainly, the decline in aspen is widespread throughout western North America (Bartos and Mueggler 1981, Kay 1993, 1997, Romme et al. 1995, White et al. 1998, Hessl 2002), but the role of variability in snowfall on elk browsing as a cause is relatively unstudied. Moreover, although precipitation has not shown clear downtrends in much of western North America, it has declined over the past century in the Southwest, with a particularly strong decline over the last quarter century (Houghton et al. 2001). If precipitation continues to decline in the Southwest together with warming, then snowfall declines could be even steeper in this region. Moreover, declines in summer precipitation can increase nest predation (Fig. 8). Finally, if water limitation is not critical to plants yet, a long-term reduction in winter precipitation could make it so.

High-elevation and riparian systems are expected to be particularly sensitive to climate change (Fyfe and Flato 1999, Houghton et al. 2001). Given that the vast majority of western bird species depend on deciduous riparian systems (Knopf 1985), loss or even reduction of the deciduous component of this important ecosystem, as observed here, is a major concern for the maintenance of biological diversity. The documentation here of the local extinction of bird species associated with the decline in deciduous plants emphasizes the potential seriousness of climate responses in mountain and southwestern riparian habitats. The evidence provided here clearly shows that, at least in sensitive ecosystems, climate change can yield significant changes in ecosystem structure and function through cascading effects among trophic levels.

\section{ACKNowledgments}

I thank D. Barton, A. Chalfoun, J. Fontaine, J. Lloyd, J. Maron, and two anonymous reviewers for helpful comments on the manuscript. I am grateful to the Mogollon Rim Ranger District of the USDA Forest Service for continued logistical support of this work. This work has been supported by the Global Climate Change Program of USGS, the National Research Initiative of the USDA Cooperative State Research, Education and Extension Service, grant number 2005-02817, and the National Science Foundation (DEB-9707598, DEB9981527, DEB-0543178).

\section{Literature Cited}

Baker, W. L., J. A. Munroe, and A. E. Hessl. 1997. The effects of elk on aspen in the winter range in Rocky Mountain National Park. Ecography 20:155-165.

Bartos, D. L., and W. F. Mueggler. 1981. Early succession in aspen communities following fire in western Wyoming. Journal of Range Management 34:315-319.

Berger, J., P. B. Stacey, L. Bellis, and M. P. Johnson. 2001. A mammalian predator-prey imbalance: grizzly bear and wolf extinction affect avian Neotropical migrants. Ecological Applications 11:947-960.

Both, C., and M. E. Visser. 2001. Adjustment to climate change is constrained by arrival date in a long distance migrant bird. Nature 411:296-298.

Brown, R. L. 1994. Elk seasonal ranges and migration in Arizona. Arizona Game and Fish Department Technical Report Number 15, Phoenix, Arizona, USA.
Christman, S. P. 1984. Plot mapping: estimating densities of breeding bird territories by combining spot mapping and transect techniques. Condor 86:237-241.

Cody, M. L., editor. 1985. Habitat selection in birds. Academic Press, New York, New York, USA.

Cook, J. G. 2002. Nutrition and food. Pages 259-349 in D. E. Toweill and J. W. Thomas, editors. North American elk: ecology and management. Smithsonian Institution Press, Washington, D.C., USA.

Crick, H. Q. P., C. Dudley, D. E. Glue, and D. L. Thomson. 1997. UK birds are laying eggs earlier. Nature 388:526-526.

Dececco, H. A., M. R. Marshall, A. B. Williams, G. A. Gale, and R. J. Cooper. 2000. Comparative seasonal fecundity of four neotropical migrants in middle Appalachia. Condor 102: 653-663.

Fyfe, J. C., and G. M. Flato. 1999. Enhanced climate change and its detection over the Rocky Mountains. Journal of Climate 12:230-243.

Hamlet, A. F., P. W. Mote, M. P. Clark, and D. P. Lettenmaier. 2005. Effects of temperature and precipitation variability on snowpack trends in the western United States. Journal of Climate 18:4545-4561.

Hensler, G. L., and J. D. Nichols. 1981. The Mayfield method of estimating nesting success: a model, estimators and simulation results. Wilson Bulletin 93:42-53.

Hessl, A. 2002. Aspen, elk, and fire: the effects of human institutions on ecosystem processes. BioScience 52:10111022.

Houghton, J. T., Y. Ding, D. J. Griggs, M. Noguer, P. J. van der Linden, X. Dai, K. Maskell, and C. A. Johnson, editors. 2001. Climate change 2001: the scientific basis. Cambridge University Press, New York, New York, USA.

Johnson, M. D., and G. R. Geupel. 1996. The importance of productivity to the dynamics of a Swainson's Thrush population. Condor 98:133-141.

Kay, C. E. 1993. Aspen seedlings in recently burned areas of Grand Teton and Yellowstone National Parks. Northwest Science 67:94-104.

Kay, C. E. 1997. Is aspen doomed? Journal of Forestry 95:4-11.

Knopf, F. L. 1985. Significance of riparian vegetation to breeding birds across an altitudinal cline. Pages 105-111 in R. R. Johnson, C. D. Ziebell, D. R. Patten, P. F. Ffolliott, and R. H. Hamre, editors. Riparian ecosystems and their management: reconciling conflicting uses. USDA Forest Service General Technical Report RM-120, Fort Collins, Colorado, USA.

Leege, T. A., and W. O. Hickey. 1977. Elk-snow-habitat relationships in the Pete King drainage. Idaho Wildlife Bulletin Number 6, Idaho Department of Fish and Game, Boise, Idaho, USA.

Martin, T. E. 1992. Breeding productivity considerations: What are the appropriate habitat features for management? Pages 455-473 in J. M. Hagan and D. W. Johnston, editors. Ecology and conservation of Neotropical migrants. Smithsonian Institution Press, Washington, D.C., USA.

Martin, T. E. 1998. Are microhabitat preferences of coexisting species under selection and adaptive? Ecology 79:656-670.

Martin, T. E. 2001. Abiotic vs. biotic influences on habitat selection of coexisting species, with implications for climate change. Ecology 82:175-188.

Martin, T. E., and G. R. Geupel. 1993. Nest-monitoring plots: methods for locating nests and monitoring success. Journal of Field Ornithology 64:507-519.

Martin, T. E., C. R. Paine, C. J. Conway, and W. Hochachka. 1996. BBIRD field protocol. USGS. 〈http://pica.wru.umt. edu/bbird/>

Mayfield, H. 1975. Suggestions for calculating nest success. Wilson Bulletin 87:456-466.

McCarthy, J. J., O. F. Canziani, N. A. Leary, D. J. Dokken, and K. S. White, editors. 2001. Climate change 2001: 
impacts, adaptations, and vulnerability. Cambridge University Press, New York, New York, USA.

McShea, W. J. 2000. The influence of acorn crops on annual variation in rodent and bird populations. Ecology 81:228238.

Mote, P. W., A. F. Hamlet, M. P. Clark, and D. P. Lettenmaier. 2005. Declining mountain snowpack in western North America. Bulletin of the American Meteorological Society 86:39-49.

Mower, K. J., and H. D. Smith. 1989. Diet similarity between elk and deer in Utah. Great Basin Naturalist 49:552-555.

O'Gara, B. W., and R. G. Dundas. 2002. Distribution: past and present. Pages 67-119 in D. E. Toweill and J. W. Thomas, editors. North American elk: ecology and management. Smithsonian Institution Press, Washington, D.C., USA.

Parmesan, C., and G. Yohe. 2003. A globally coherent fingerprint of climate change impacts across natural systems. Nature 421:36-42.

Petit, L. J., and D. R. Petit. 1996. Factors governing habitat selection by Prothonotary Warblers: field tests of the Fretwell-Lucas models. Ecological Monographs 66:367-387.

Phillips, S. L., and J. R. Ehleringer. 1995. Limited uptake of summer precipitation by bigtooth maple (Acer grandidentatum Nutt) and Gambel's oak (Quercus gambelii Nutt). Trees 9:214-219

Post, E., R. O. Peterson, N. C. Stenseth, and B. E. McLaren. 1999. Ecosystem consequences of wolf behavioral response to climate. Nature 401:905-907.

Romme, W. H., M. G. Turner, L. L. Wallace, and J. S. Walker. 1995. Aspen, elk, and fire in northern Yellowstone National Park. Ecology 76:2097-2106.

Root, T. L., J. T. Price, K. R. Hall, S. H. Schneider, C. Rosenzweig, and J. A. Pounds. 2003. Fingerprints of global warming on wild animals and plants. Nature 421:57-60.

Root, T. L., and S. H. Schneider. 1995. Ecology and climate: research strategies and implications. Science 269:334-341.
Schwinning, S., K. Davis, L. Richardson, and J. R. Ehleringer. 2002. Deuterium enriched irrigation indicates different forms of rain use in shrub/grass species of the Colorado Plateau. Oecologia 130:345-355.

Sillett, T. S., R. T. Holmes, and T. W. Sherry. 2000. Impacts of a global climate cycle on population dynamics of a migratory songbird. Science 288:2040-2042.

Stevenson, I. R., and D. M. Bryant. 2000. Avian phenology: climate change and constraints on breeding. Nature 406:366367.

Sweeney, J. M., and H. W. Steinhoff. 1976. Elk movements and calving as related to snow cover. Pages 415-436 in H. W. Steinhoff and J. D. Ives, editors. Ecological impacts of snowpack augmentation in the San Juan Mountains, Colorado. Colorado State University, Fort Collins, Colorado, USA.

Visser, M. E., et al. 2003. Variable responses to large-scale climate change in European Parus populations. Proceedings of the Royal Society of London B 270:367-372.

Visser, M. E., A. J. Van Noordwijk, J. M. Tinbergen, and C. M. Lessells. 1998. Warmer springs lead to mistimed reproduction in Great Tits (Parus major). Proceedings of the Royal Society of London B 265:1867-1870.

White, C. A., C. E. Olmsted, and C. E. Kay. 1998. Aspen, elk, and fire in the Rocky Mountain national parks of North America. Wildlife Society Bulletin 26:449-462.

Williams, D. G., and J. R. Ehleringer. 2000. Intra- and interspecific variation for summer precipitation use in pinyon-juniper woodlands. Ecological Monographs 700: 517-537.

Winkler, D. W., P. O. Dunn, and C. E. McCulloch. 2002. Predicting the effects of climate change on avian life-history traits. Proceedings of the National Academy of Sciences (USA) 99:13595-13599.

\section{APPENDIX A}

Locations and elevations of plots at station 1 (the first station of each plot) (Ecological Archives E088-022-A1).

\section{APPENDIX B}

Number of stems by size/age class within $5 \mathrm{~m}$ radius circles for major plant species near the beginning (1987) and latest year (2005) of study (Ecological Archives E088-022-A2).

\section{APPENDIX C}

Additional details concerning fire history, study area extension, and weather station data for the study site (Ecological Archives E088-022-A3) 